\title{
Novel steroids from the soft coral Nephthea chabrolii
}

\author{
Jui-Hsin Su, ${ }^{\text {a }}$ Fang-Yee Lin, ${ }^{\text {a }}$ Ho-Cheng Huang, ${ }^{\mathrm{b}}$ Chang-Feng Dai, ${ }^{\mathrm{c}}$ Yang-Chang Wu, ${ }^{\mathrm{d}}$ \\ Wan-Ping $\mathrm{Hu},{ }^{\mathrm{e}}$ Chi-Hsin Hsu, ${ }^{\mathrm{a}, \mathrm{e}}$ and Jyh-Horng Sheu ${ }^{\mathrm{a}, \mathrm{f}, *}$ \\ ${ }^{a}$ Department of Marine Biotechnology and Resources, National Sun Yat-sen University, Kaohsiung 804, Taiwan \\ ${ }^{\mathrm{b}}$ Department of Chemical Engineering, Cheng Shiu University, Kaohsiung 833, Taiwan \\ ${ }^{\mathrm{c}}$ Institute of Oceanography, National Taiwan University, Taipei 112, Taiwan \\ ${ }^{\mathrm{d}}$ Institute of Natural Products, Kaohsiung Medical University, Kaohsiung 807, Taiwan \\ ${ }^{\mathrm{e}}$ Faculty of Biotechnology, Kaohsiung Medical University, Kaohsiung 807, Taiwan

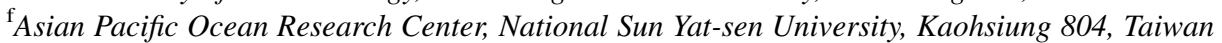

Received 3 October 2006; revised 26 October 2006; accepted 30 October 2006

Available online 17 November 2006

\begin{abstract}
Three new metabolites including two new steroids, chabrolosteroids A and B (1 and 2), and a novel spirosteroid chabrolosteroid C (3), were isolated from the organic extract of a Taiwanese soft coral Nephthea chabrolii. The structures of these metabolites were elucidated by extensive spectroscopic analysis and by comparison of the spectral data with those of related steroids. This is the first report of a steroid with a spiro-ring A, B system in natural products.

(c) 2006 Elsevier Ltd. All rights reserved.
\end{abstract}

\section{Introduction}

Our previous study on the secondary metabolites of a Formosan soft coral Nephthea chabrolii Audouin (Alcyonacea, Nephthedae) has resulted in the isolation of a series of new meroditerpenoids, including naphthoquinone derivatives, tetraprenyltoluquinone-related metabolites, and tetraprenyltoluquinol-related metabolites. ${ }^{1,2}$ Our continuing investigation on the chemical constituents of the EtOH extract of this soft coral again has afforded three new steroids. Among these metabolites $\mathbf{3}$ was found to possess a novel skeleton.

\section{Results and discussion}

A collection of $N$. chabrolii was homogenized with EtOH and filtered, and further extracted with EtOH. The combined extracts were concentrated and subsequently subjected to further purification to yield the new compounds $\mathbf{1}-\mathbf{3}$ (Fig. 1).

Chabrolosteroid A (1) was isolated as a white powder. Its molecular formula $\mathrm{C}_{28} \mathrm{H}_{44} \mathrm{O}_{3}$ was established by HRESIMS $\left(m / z\right.$ 451.3186, $\left.[\mathrm{M}+\mathrm{Na}]^{+}\right)$, implying seven degrees of unsaturation. The presence of hydroxy functionality was suggested by a strong absorption band at $3404 \mathrm{~cm}^{-1}$ in the IR spectrum. By the analysis of NMR (Table 1) and DEPT

Keywords: Chabrolosteroids; Spirosteroid; Nephthea chabrolii.

* Corresponding author. Tel.: +886 7 5252000x5030; fax: +886 7 5255020; e-mail: sheu@mail.nsysu.edu.tw spectra of $\mathbf{1}$, measured in $\mathrm{CDCl}_{3}$, the carbon signals were assigned to five methyl, nine $\mathrm{sp}^{3}$ methylenes (including one oxygenated $\delta 65.8)$, six sp $\mathrm{s}^{3}$ methines, three $\mathrm{sp}^{2}$ methines, and five quaternary carbons. By comparison of some NMR data of $1, \delta 186.5(\mathrm{C}), 169.5(\mathrm{C}), 156.1(\mathrm{CH}), 127.4(\mathrm{CH})$, and $123.7(\mathrm{CH})$ with those of the previously reported steroids, ${ }^{3,4}$ it was also found that the carbon signals appearing were similar to those of steroids with a cross-conjugated dienone structural unit in the ring $\mathrm{A}$. The absorptions of the UV $(248 \mathrm{~nm})$ and IR $\left(1658 \mathrm{~cm}^{-1}\right)$ spectra further confirmed

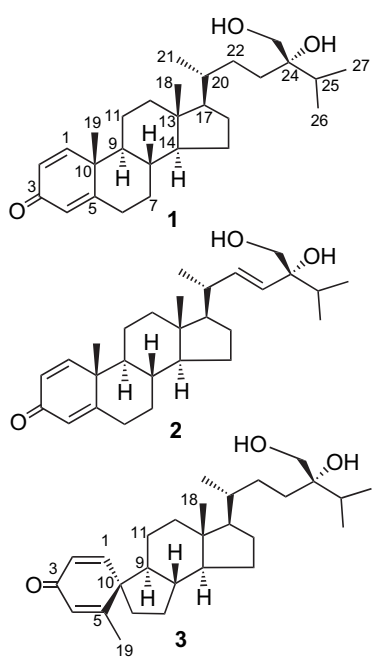

Figure 1. Structures of new metabolites 1-3. 
Table 1. ${ }^{1} \mathrm{H}$ and ${ }^{13} \mathrm{C}$ NMR chemical shifts of compounds $\mathbf{1}-\mathbf{3}$

\begin{tabular}{|c|c|c|c|c|c|c|}
\hline \multirow[t]{2}{*}{ No. } & \multicolumn{2}{|l|}{1} & \multicolumn{2}{|l|}{2} & \multicolumn{2}{|l|}{3} \\
\hline & $\overline{\delta_{\mathrm{H}}}{ }^{\mathrm{a}}$ & $\delta_{\mathrm{C}}^{\mathrm{b}}$ & $\overline{\delta_{\mathrm{H}}{ }^{\mathrm{a}}}$ & $\delta_{\mathrm{C}}^{\mathrm{b}}$ & $\overline{\delta_{\mathrm{H}}}{ }^{\mathrm{a}}$ & $\delta_{\mathrm{C}}^{\mathrm{b}}$ \\
\hline 1 & $7.06 \mathrm{~d}(10.0)^{\mathrm{c}}$ & $156.1(\mathrm{CH})^{\mathrm{d}}$ & $7.06 \mathrm{~d}(10.0)$ & $156.0(\mathrm{CH})$ & $6.87 \mathrm{~d}(10.0)$ & $154.8(\mathrm{CH})$ \\
\hline 2 & $6.23 \mathrm{dd}(10.0,2.0)$ & $127.4(\mathrm{CH})$ & $6.23 \mathrm{dd}(10.0,2.0)$ & $127.5(\mathrm{CH})$ & $6.20 \mathrm{~d}(10.0)$ & $126.6(\mathrm{CH})$ \\
\hline 3 & & $186.5(\mathrm{C})$ & & $186.4(\mathrm{C})$ & & $186.6(\mathrm{C})$ \\
\hline 4 & $6.07 \mathrm{~s}$ & $123.7(\mathrm{CH})$ & $6.07 \mathrm{~s}$ & $123.8(\mathrm{CH})$ & $6.17 \mathrm{~s}$ & $128.6(\mathrm{CH})$ \\
\hline 5 & & $169.5(\mathrm{C})$ & & $169.4(\mathrm{C})$ & & $163.2(\mathrm{C})$ \\
\hline 6 & $2.35 \mathrm{dt}(12.0,2.5)$ & $32.9\left(\mathrm{CH}_{2}\right)$ & $2.37 \mathrm{dt}(12.0,3.0)$ & $32.9\left(\mathrm{CH}_{2}\right)$ & $1.76 \mathrm{~m}$ & $34.9\left(\mathrm{CH}_{2}\right)$ \\
\hline & 2.46 ddd $(13.5,12.0,5.5)$ & & 2.46 ddd $(13.5,13.0,5.5)$ & & $1.99 \mathrm{~m}$ & \\
\hline 7 & $1.02 \mathrm{~m} ; 1.94 \mathrm{~m}$ & $33.7\left(\mathrm{CH}_{2}\right)$ & $1.04 \mathrm{~m} ; 1.94 \mathrm{~m}$ & $33.6\left(\mathrm{CH}_{2}\right)$ & $1.33 \mathrm{~m} ; 1.98 \mathrm{~m}$ & $30.6\left(\mathrm{CH}_{2}\right)$ \\
\hline 8 & $1.63 \mathrm{~m}$ & $35.5(\mathrm{CH})$ & $1.61 \mathrm{~m}$ & $35.5(\mathrm{CH})$ & $1.57 \mathrm{~m}$ & $56.5(\mathrm{CH})$ \\
\hline 9 & $1.04 \mathrm{~m}$ & $52.3(\mathrm{CH})$ & $1.06 \mathrm{~m}$ & $52.3(\mathrm{CH})$ & $1.77 \mathrm{~m}$ & $42.5(\mathrm{CH})$ \\
\hline 10 & & $43.6(\mathrm{C})$ & & $43.6(\mathrm{C})$ & & $52.6(\mathrm{C})$ \\
\hline 11 & $1.68 \mathrm{~m}$ & $22.8\left(\mathrm{CH}_{2}\right)$ & $1.68 \mathrm{~m}$ & $22.8\left(\mathrm{CH}_{2}\right)$ & $1.78 \mathrm{~m}$ & $22.1\left(\mathrm{CH}_{2}\right)$ \\
\hline 12 & $1.16 \mathrm{~m} ; 2.04 \mathrm{dt}(12.5,3.5)$ & $39.4\left(\mathrm{CH}_{2}\right)$ & $1.21 \mathrm{~m} ; 2.02 \mathrm{dt}(12.5,3.5)$ & $39.3\left(\mathrm{CH}_{2}\right)$ & $1.95 \mathrm{~m}$ & $39.3\left(\mathrm{CH}_{2}\right)$ \\
\hline 13 & & $42.7(\mathrm{C})$ & & $42.6(\mathrm{C})$ & & $43.6(\mathrm{C})$ \\
\hline 14 & $0.99 \mathrm{~m}$ & $55.4(\mathrm{CH})$ & $1.03 \mathrm{~m}$ & $55.4(\mathrm{CH})$ & $1.17 \mathrm{~m}$ & $56.4(\mathrm{CH})$ \\
\hline 15 & $1.12 \mathrm{~m} ; 1.61 \mathrm{~m}$ & $24.4\left(\mathrm{CH}_{2}\right)$ & $1.57 \mathrm{~m}$ & $24.4\left(\mathrm{CH}_{2}\right)$ & $1.62 \mathrm{~m}$ & $24.6\left(\mathrm{CH}_{2}\right)$ \\
\hline 16 & $1.30 \mathrm{~m} ; 1.88 \mathrm{~m}$ & $28.1\left(\mathrm{CH}_{2}\right)$ & $1.67 \mathrm{~m}$ & $28.7\left(\mathrm{CH}_{2}\right)$ & $1.32 \mathrm{~m} ; 1.91 \mathrm{~m}$ & $28.5\left(\mathrm{CH}_{2}\right)$ \\
\hline 17 & $1.13 \mathrm{~m}$ & $55.6(\mathrm{CH})$ & $1.20 \mathrm{~m}$ & $55.5(\mathrm{CH})$ & $1.16 \mathrm{~m}$ & $55.2(\mathrm{CH})$ \\
\hline 18 & $0.74 \mathrm{~s}$ & $12.0\left(\mathrm{CH}_{3}\right)$ & $0.77 \mathrm{~s}$ & $12.3\left(\mathrm{CH}_{3}\right)$ & $0.66 \mathrm{~s}$ & $12.2\left(\mathrm{CH}_{3}\right)$ \\
\hline 19 & $1.23 \mathrm{~s}$ & $18.7\left(\mathrm{CH}_{3}\right)$ & $1.23 \mathrm{~s}$ & $18.7\left(\mathrm{CH}_{3}\right)$ & $1.97 \mathrm{~s}$ & $19.5\left(\mathrm{CH}_{3}\right)$ \\
\hline 20 & $1.40 \mathrm{~m}$ & $36.1(\mathrm{CH})$ & $2.17 \mathrm{~m}$ & $40.2(\mathrm{CH})$ & $1.39 \mathrm{~m}$ & $36.0(\mathrm{CH})$ \\
\hline 21 & $0.93 \mathrm{~d}(6.0)$ & $18.6\left(\mathrm{CH}_{3}\right)$ & $1.05 \mathrm{~d}(6.0)$ & $20.7\left(\mathrm{CH}_{3}\right)$ & $0.94 \mathrm{~d}(6.0)$ & $18.7\left(\mathrm{CH}_{3}\right)$ \\
\hline 22 & $1.05 \mathrm{~m} ; 1.40 \mathrm{~m}$ & $28.8\left(\mathrm{CH}_{2}\right)$ & $5.58 \mathrm{dd}(15.5,9.0)$ & $138.5(\mathrm{CH})$ & $1.07 \mathrm{~m} ; 1.36 \mathrm{~m}$ & $29.0\left(\mathrm{CH}_{2}\right)$ \\
\hline 23 & $1.33 \mathrm{~m} ; 1.64 \mathrm{~m}$ & $30.3\left(\mathrm{CH}_{2}\right)$ & $5.31 \mathrm{~d}(15.5)$ & $127.8(\mathrm{CH})$ & $1.33 \mathrm{~m} ; 1.64 \mathrm{~m}$ & $30.3\left(\mathrm{CH}_{2}\right)$ \\
\hline 24 & & $76.1(\mathrm{C})$ & & $77.4(\mathrm{C})$ & & $76.1(\mathrm{C})$ \\
\hline 25 & $1.86 \mathrm{~m}$ & $32.4(\mathrm{CH})$ & $1.81 \mathrm{~m}$ & $34.0(\mathrm{CH})$ & $1.85 \mathrm{~m}$ & $32.5(\mathrm{CH})$ \\
\hline 26 & $0.93 \mathrm{~d}(7.0)$ & $17.0\left(\mathrm{CH}_{3}\right)$ & $0.88 \mathrm{~d}(7.0)$ & $17.5\left(\mathrm{CH}_{3}\right)$ & $0.93 \mathrm{~d}(7.5)$ & $16.9\left(\mathrm{CH}_{3}\right)$ \\
\hline 27 & $0.91 \mathrm{~d}(7.0)$ & $16.9\left(\mathrm{CH}_{3}\right)$ & $0.90 \mathrm{~d}(7.0)$ & $16.5\left(\mathrm{CH}_{3}\right)$ & $0.92 \mathrm{~d}(7.5)$ & $17.0\left(\mathrm{CH}_{3}\right)$ \\
\hline 28 & $3.45 \mathrm{~d}(11.0) ; 3.61 \mathrm{~d}(11.0)$ & $65.8\left(\mathrm{CH}_{2}\right)$ & $3.53 \mathrm{~s}$ & $67.6\left(\mathrm{CH}_{2}\right)$ & $3.46 \mathrm{~d}(10.0) ; 3.61 \mathrm{~d}(10.0)$ & $65.9\left(\mathrm{CH}_{2}\right)$ \\
\hline
\end{tabular}

a Spectra recorded at $500 \mathrm{MHz}$ in $\mathrm{CDCl}_{3}$.

b Spectra recorded at $125 \mathrm{MHz}$ in $\mathrm{CDCl}_{3}$.

c $J$ values $(\mathrm{Hz})$ in parentheses.

d Attached protons determined by DEPT experiments.

the presence of this moiety as an important structural unit of 1. Careful analysis of the ${ }^{1} \mathrm{H}-{ }^{1} \mathrm{H}$ COSY correlations observed for 1 has led to the establishment of five partial structures, as shown in Figure 2. The molecular framework of $\mathbf{1}$ was further established by an HMBC experiment (Fig. 2). The structures and connection among $\mathrm{A}, \mathrm{B}, \mathrm{C}$, and $\mathrm{D}$ rings were elucidated on the basis of the following $\mathrm{HMBC}$ correlations: $\mathrm{H}-1$ to $\mathrm{C}-3, \mathrm{C}-5$, and $\mathrm{C}-10$; $\mathrm{H}-2$ to $\mathrm{C}-1$ and $\mathrm{C}-10$; $\mathrm{H}-4$ to C-2 and C-6; $\mathrm{H}_{2}-6$ to $\mathrm{C}-5$ and C-10; $\mathrm{H}-9$ to $\mathrm{C}-14 ; \mathrm{H}_{2}-12$ to $\mathrm{C}-13 ; \mathrm{H}_{2}-15$ to $\mathrm{C}-13 ; \mathrm{H}_{2}-16$ to $\mathrm{C}-14 ; \mathrm{H}-17$ to $\mathrm{C}-13, \mathrm{C}-20$, and $\mathrm{C}-22 ; \mathrm{H}_{3}-18$ to $\mathrm{C}-12, \mathrm{C}-13, \mathrm{C}-14$, and $\mathrm{C}-17 ; \mathrm{H}_{3}-19$ to C-1, C-5, C-9, and C-10. The planar structure of the side chain was elucidated mainly by the key HMBC correlations from $\mathrm{H}_{2}-28$ to $\mathrm{C}-23, \mathrm{C}-24$, and $\mathrm{C}-25$. On the basis of the

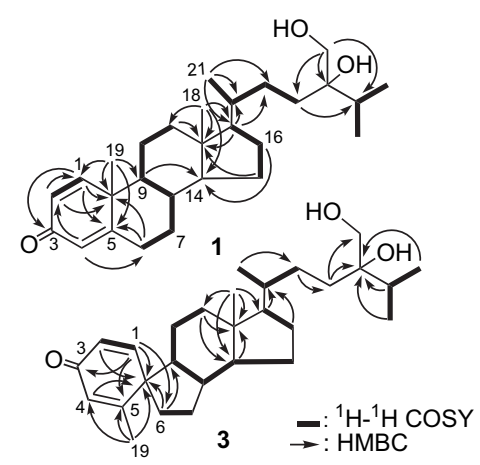

Figure 2. Selective ${ }^{1} \mathrm{H}-{ }^{1} \mathrm{H}$ COSY and HMBC correlations of $\mathbf{1}$ and $\mathbf{3}$. above findings and HMBC correlations observed, the skeleton of 1 could be established unambiguously.

The stereochemistry regarding C-8, C-9, C-10, C-13, C-14, $\mathrm{C}-17$, and $\mathrm{C}-20$ in $\mathbf{1}$ was found to be the same by comparison of the NMR data $\left({ }^{1} \mathrm{H}\right.$ and $\left.{ }^{13} \mathrm{C}\right)$ with those of the related known compounds. $^{3,4}$ This was further established by a NOESY experiment, which showed the following key correlations: $\mathrm{H}-6 \beta, \mathrm{H}-7 \beta, \mathrm{H}_{3}-18$, and $\mathrm{H}_{3}-19$ with $\mathrm{H}-8$; $\mathrm{H}-6 \beta$ with $\mathrm{H}_{3}-19$; $\mathrm{H}-6 \alpha$ and $\mathrm{H}-7 \alpha$ with $\mathrm{H}-9$; $\mathrm{H}-11 \beta$ with $\mathrm{H}_{3}-18$; $\mathrm{H}_{3}-18$ with $\mathrm{H}-20$; $\mathrm{H}-11 \alpha$ and $\mathrm{H}-17$ with $\mathrm{H}-14$. The absolute configuration at C-24 was determined by comparison of the NMR data of $\mathbf{1}$ in $\mathrm{CD}_{3} \mathrm{OD}$ with those of two related synthetic compounds, also measured in $\mathrm{CD}_{3} \mathrm{OD}$. The difference between the proton shifts of two protons at C-28, $\Delta \delta_{\mathrm{H}}=$ $0.06 \mathrm{ppm}$, was found to be the same as those of $24 S-24-$ hydroxymethyl-24-hydroxycholesterol $4\left(\Delta \delta_{\mathrm{H}}=0.06 \mathrm{ppm}\right)$, while its $24 R$-epimer $\mathbf{5}$ showed the chemical shift difference of these two protons, $\Delta \delta_{\mathrm{H}}=0.04 \mathrm{ppm} .^{5}$ Also, the carbon shift of C-28 $(\delta=66.4)$ was found to be more closer to that of $4(\delta=66.3)$ relative to that of $5(\delta=66.0)$, too. Moreover, metabolite 1 has the nearly identical NMR shifts of $\mathrm{H}_{2}-28$ and C-28 as those of a known compound certonardosterol $\mathrm{B}_{4}(\mathbf{6})^{6}$ (Fig. 3). Thus, it was suggested that the stereochemistry of 1 at C-24 should be $24 S$. The C-24 configuration of 1 was further confirmed by comparison of the ${ }^{1} \mathrm{H}$ NMR data of its $(R)$ - and $(S)$-MTPA esters with those of $\mathbf{4}$ and $\mathbf{5}$. It has been reported that the $\mathrm{H}_{2}-28$ signals of the $(R)$-MTPA ester of 4 appeared at $\delta 4.33$ and 4.21, and those of $(R)$-MTPA ester of 5 appeared at $\delta 4.37$ and 4.17 , while the $\mathrm{H}_{2}-28$ signals 

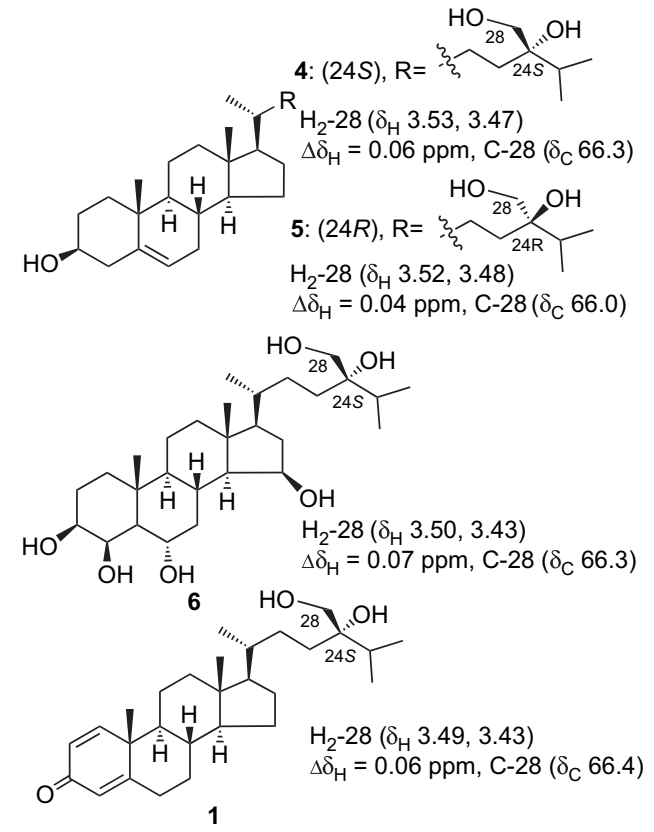

Figure 3. Selective ${ }^{1} \mathrm{H}$ and ${ }^{13} \mathrm{C}$ NMR data measured in $\mathrm{CD}_{3} \mathrm{OD}$ for $\mathbf{1}$, and 4-6 $\left(\Delta \delta_{\mathrm{H}}=\delta_{\mathrm{H}-28 \mathrm{a}}-\delta_{\mathrm{H}-28 \mathrm{~b}}\right)$.

of the (S)-MTPA ester of 4 appeared at $\delta 4.41$ and 4.14 and those of the $(S)$-MTPA ester of 5 appeared at $\delta 4.30$ and $4.23 .{ }^{5}$ We found that the $\mathrm{H}_{2}-28$ signals of the $(S)$-MTPA ester of 1 appeared as two well-separated doublets at $\delta 4.40$ and $4.13\left(\delta_{\mathrm{H}}=0.27 \mathrm{ppm}\right)$, while those of the $(R)$-MTPA ester appeared as two closely spaced doublets at $\delta 4.32$ and 4.20 $\left(\delta_{\mathrm{H}}=0.12 \mathrm{ppm}\right)$. Thus, 1 should possess $24 S$ configuration, the same as that of $\mathbf{4}$. On the basis of the above analysis, the structure of 1 was established.

Chabrolosteroid B (2) was obtained as a white powder, which exhibited a pseudomolecular ion peak $[\mathrm{M}+\mathrm{Na}]^{+}$at $m / z 449.3029$ in the HRESIMS. The ${ }^{1} \mathrm{H}$ and ${ }^{13} \mathrm{C}$ NMR spectra (Table 1) for the tetracyclic moiety of $\mathbf{2}$ were similar to those of 1. However, the NMR data of the side chain of $\mathbf{2}$ showed the presence of an additional double bond $[\delta 5.58$ (1H, dd, $J=15.5,9.0 \mathrm{~Hz}, \mathrm{H}-22), 5.31(1 \mathrm{H}, \mathrm{d}, J=15.5 \mathrm{~Hz}$, $\mathrm{H}-23), 138.5$ (CH, C-22), 127.8 (CH, C-23)] by comparison of those of 1 . The HMBC correlations between methyl protons at $\delta 1.05(3 \mathrm{H}, \mathrm{d}, J=6.0 \mathrm{~Hz}, \mathrm{H}-21)$ and $\mathrm{C}-20(\delta 40.2$, $\mathrm{CH}), \mathrm{C}-22$, and $\mathrm{C}-17(\delta 55.5, \mathrm{CH})$, further assigned the position of the double bond at $\mathrm{C}-22$ and $\mathrm{C}-23$. The coupling constant $(15.5 \mathrm{~Hz})$ between two olefinic protons confirmed the $E$-geometry of 22,23-double bond. Although it was found that the stereochemistry at C-24 could not be firmly established by the NOESY experiment, which showed the following NOE interactions for protons near C-24: $\mathrm{H}-22 /$ $\mathrm{H}-17, \mathrm{H}-22 / \mathrm{H}_{3}-21, \mathrm{H}-23 / \mathrm{H}-20, \mathrm{H}-23 / \mathrm{H}-25, \mathrm{H}-23 / \mathrm{H}_{3}-26$, $\mathrm{H}-23 / \mathrm{H}_{2}-28, \mathrm{H}_{2}-28 / \mathrm{H}-25$, and $\mathrm{H}_{2}-28 / \mathrm{H}_{3}-27$, as these NOEs could appear in both $24 R$ and $24 S$ configurations, however, based on the well established $24 S$ configuration of $\mathbf{1}$ and by the fact that both $\mathbf{1}$ and $\mathbf{2}$ could be the precursors of each other by dehydrogenation and hydrogenation, respectively, the structure of $\mathbf{2}$ was then established as shown.

The HRESIMS of chabrolosteroid (3) exhibited a pseudomolecular ion peak at $m / z 451.3186[\mathrm{M}+\mathrm{Na}]^{+}$. This information along with the ${ }^{13} \mathrm{C}$ NMR (Table 1) and the DEPT spectra, which assigned the 28 carbons into five methyls, nine methylenes, nine methines, and five quaternary carbons, allowed the determination of the molecular formula as $\mathrm{C}_{28} \mathrm{H}_{44} \mathrm{O}_{3}$. The ${ }^{1} \mathrm{H}$ NMR spectrum of $\mathbf{3}$ exhibited three doublet methyl signals at $\delta 0.92,0.93$, and 0.94 , two singlet methyl signals at $\delta 0.66$ and 1.97 , an oxygenated methylene group at $\delta 3.46$ and 3.61 (each $\mathrm{d}, J=10.0 \mathrm{~Hz}$ ), and three olefinic protons at $\delta 6.17(\mathrm{~s}), 6.20(\mathrm{~d}, J=10.0 \mathrm{~Hz})$, and $6.87 \mathrm{ppm}(\mathrm{d}$, $J=10.0 \mathrm{~Hz}$ ). The planar structure of $\mathbf{3}$ was further established by the 2D NMR studies, particularly in ${ }^{1} \mathrm{H}-{ }^{1} \mathrm{H}$ COSY, HMQC, and HMBC experiments (Fig. 2). The proton sequence from $\mathrm{H}-1(\delta 6.87,1 \mathrm{H})$ to $\mathrm{H}-2(\delta 6.20,1 \mathrm{H})$ and the HMBC correlations from $\mathrm{H}-1$ to $\mathrm{C}-3(\delta 186.6, \mathrm{C}), \mathrm{C}-5$ $(\delta$ 163.2, C), C-10 $(\delta 52.6, \mathrm{C})$, both $\mathrm{H}-2$ and $\mathrm{H}-4(\delta 6.17$, $1 \mathrm{H})$ to $\mathrm{C}-10$, and $\mathrm{H}_{3}-19(\delta 1.97,3 \mathrm{H}, \mathrm{s})$ to $\mathrm{C}-4(\delta 128.6$, $\mathrm{CH}), \mathrm{C}-5$, and $\mathrm{C}-10$, suggested a dienone moiety in $\mathbf{3}$. The above information, together with the HMBC information from $\mathrm{H}-1$ to C-6 and H-6 to C-9 and C-10, established a spiro[4,5]decane with the 3-oxo-1,4-diene substructure in the $\mathrm{A}$ ring of 3. It was found that the remaining structure, including rings $C$ and $D$, and the side chain of $\mathbf{3}$, is identical to that of $\mathbf{1}$ by comparison of the related $1 \mathrm{D}\left({ }^{1} \mathrm{H}\right.$ and $\left.{ }^{13} \mathrm{C}\right)$ and $2 \mathrm{D} \mathrm{NMR}$ data, particularly in ${ }^{1} \mathrm{H}-{ }^{1} \mathrm{H}$ COSY and HMBC correlations. The stereochemistry of compound $\mathbf{3}$ was determined by the NOESY spectrum (Fig. 4), which exhibited NOE correlations between $\mathrm{H}-1$ and $\mathrm{H}-6 \alpha(\delta 1.76)$, and $\mathrm{H}-8$ and $\mathrm{H}_{3}-19$, and established the $\beta$-orientation of $\mathrm{C}-5$, and the $\alpha$-orientation of $\mathrm{C}-1$. The configurations of other chiral centers were confirmed by other key NOE correlations and by comparison of the NMR spectral data of side-chain protons and carbons with those of $\mathbf{1}$. All of these findings were found to be in full agreement with the $R$ and $S$ configurations at C-10 and C-24, respectively. Therefore, the structure of steroid $\mathbf{3}$, with a spiro-ring A, B system, was established. Compound $\mathbf{3}$ is the first natural product possessing this molecular skeleton.

The biosynthetic pathway of the novel spirosteroid $\mathbf{3}$ was proposed as shown in Scheme 1. The cross-conjugated dienone moiety of $\mathbf{1}$ was protonated at the carbonyl oxygen

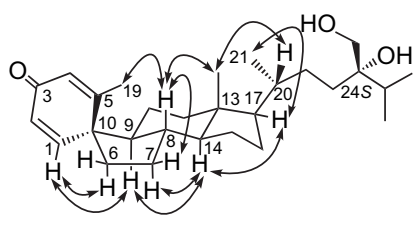

Figure 4. Selective NOESY correlations of 3.

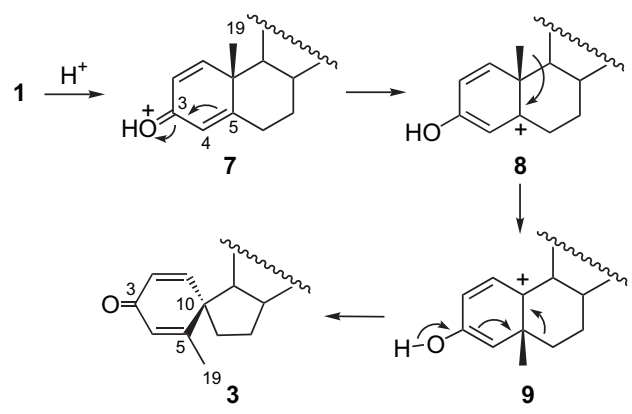

Scheme 1. Proposed biosynthetic pathways of $\mathbf{3}$. 
to form the intermediate 7 , which could appear as an enol allylic carbonium ion $\mathbf{8}$ via resonance. The following 1,2shift of the methyl substitution at C-10 afforded a carbonium ion 9, which has a positive charge at $\mathrm{C}-10$. The subsequent 1,2-shift of C-6 from C-5 to C-10 and the following deprotonation, would complete the biosynthesis of $\mathbf{3}$.

The cytotoxicity of compounds $\mathbf{1}-\mathbf{3}$ against the proliferation of a limited cancer cell lines, including human hepatocellular carcinomas (Hep G2 and Hep 3B), human breast carcinomas (MCF-7 and MDA-MB-231), and human lung carcinoma (A-549) was studied. It was found that $\mathbf{1}$ and $\mathbf{3}$ are not cytotoxic toward the above cancer cells. Metabolite 2 has been shown to exhibit a weak cytotoxicity toward Hep 3B ( $\left.\mathrm{IC}_{50} 19.9 \mu \mathrm{g} / \mathrm{mL}\right)$ cancer cell line, but is not active against the growth of other cancer cells.

\section{Experimental}

\subsection{General experimental procedures}

Melting points were determined using a Fisher-Johns melting point apparatus. Optical rotations were measured on a Jasco DIP-1000 digital polarimeter. IR spectra were recorded on a Hitachi I-2001 infrared spectrophotometer. Ultraviolet spectra were recorded on a Hitachi U-3210 UV spectrophotometer. NMR spectra were recorded on a Bruker AVANCE DPX300 FT-NMR at $300 \mathrm{MHz}$ for ${ }^{1} \mathrm{H}$ and $75 \mathrm{MHz}$ for ${ }^{13} \mathrm{C}$ or on a Varian Unity INOVA 500 FT-NMR at $500 \mathrm{MHz}$ for ${ }^{1} \mathrm{H}$ and $125 \mathrm{MHz}$ for ${ }^{13} \mathrm{C}$. Low-resolution MS data were obtained by ESI on a Bruker APEX II mass spectrometer. HRMS were recorded on ESI on a Bruker APEX II mass spectrometer. Silica gel (Merck, 230-400 mesh) was used for column chromatography. Precoated silica gel plates (Merck, Kieselgel 60 F-254, $0.2 \mathrm{~mm}$ ) were used for analytical TLC. Isolation by HPLC was performed by Shimadzu SPD-10A instrument equipped with a normal phase column (Lichrosorb Si-60, $7 \mu \mathrm{m}, 250 \times 25 \mathrm{~mm}$ ).

\subsection{Organism}

The soft coral $N$. chabrolii was collected by hand using SCUBA off the coast of Pingtung county, southern Taiwan, in July 2001, at depths of 15-20 m, and stored in a freezer until extraction. A voucher sample was deposited at the Department of Marine Biotechnology and Resources, National Sun Yat-sen University.

\subsection{Extraction and separation}

The sliced bodies of $N$. chabrolii $(1.8 \mathrm{~kg}$, wet wt) were exhaustively homogenized with EtOH and filtered. The ground organism was repeatedly extracted with EtOH. The combined EtOH extract was concentrated under vacuum to afford a dark brown viscous residue $(20.8 \mathrm{~g})$. The residue was triturated with $n$-hexane to afford an $n$-hexane soluble fraction, and then with EtOAc. The combined EtOAc soluble fraction was evaporated under vacuum to yield an oily residue $(15.8 \mathrm{~g})$, which was subjected to column chromatography on $\mathrm{Si}$ gel, using $n$-hexane, $n$-hexane and EtOAc mixtures of increasing polarity, and finally pure EtOAc, to yield 28 fractions. Fraction 20 eluted with $n$-hexane-EtOAc
(1:1), was further purified by normal phase HPLC using $\mathrm{MeOH}-\mathrm{CH}_{2} \mathrm{Cl}_{2}(1: 100)$ to afford $1(4.0 \mathrm{mg}), 2(1.8 \mathrm{mg})$, and 3 (0.8 $\mathrm{mg})$.

3.3.1. Chabrolosteroid A (1). White powder; mp 183$185^{\circ} \mathrm{C} ;[\alpha]_{\mathrm{D}}^{25}-23\left(c 1.04, \mathrm{CHCl}_{3}\right)$; UV $(\mathrm{MeOH}) \lambda_{\max }$ $248 \mathrm{~nm}$; IR (neat) $\nu_{\max } 3404,1658 \mathrm{~cm}^{-1} ;{ }^{1} \mathrm{H}(500 \mathrm{MHz}$, $\left.\mathrm{CDCl}_{3}\right)$ and ${ }^{13} \mathrm{C}\left(125 \mathrm{MHz}, \mathrm{CDCl}_{3}\right) \mathrm{NMR}$, see Table 1; ${ }^{1} \mathrm{H}$ NMR $\left(500 \mathrm{MHz}, \mathrm{CD}_{3} \mathrm{OD}\right) \delta_{\mathrm{H}}: 7.29(1 \mathrm{H}, \mathrm{d}, J=10.0 \mathrm{~Hz}$, H-1), 6.21 (1H, dd, J=10.0, $1.5 \mathrm{~Hz}, \mathrm{H}-2), 6.06$ (1H, s, H-4), 3.49 (1H, d, J=11.0 Hz, H-28), $3.43(1 \mathrm{H}, \mathrm{d}$, $J=11.0 \mathrm{~Hz}, \mathrm{H}-28), 2.57$ (1H, ddd, $J=13.0,8.0,5.0 \mathrm{~Hz}$,

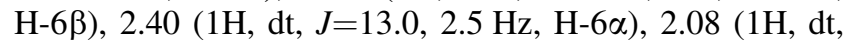
$J=12.5,3.0 \mathrm{~Hz}, \mathrm{H}-12 \beta), 1.99$ (1H, m, H-7 $\alpha), 1.91$ (1H, m, H-16), 1.82 (1H, m, H-25), 1.74 (1H, m, H-11), $1.72(1 \mathrm{H}$, m, H-8), 1.66 (1H, m, H-23), 1.62 (1H, m, H-15), 1.46 (1H, m, H-22), 1.39 (1H, m, H-20), 1.32 (1H, m, H-23), $1.28\left(3 \mathrm{H}, \mathrm{s}, \mathrm{H}_{3}-19\right), 1.18(1 \mathrm{H}, \mathrm{m}, \mathrm{H}-12 \alpha), 1.16(1 \mathrm{H}, \mathrm{m}$, H-17), 1.08 (1H, m, H-22), 1.04 (1H, m, H-14), 1.03 (1H, $\mathrm{m}, \mathrm{H}-7 \beta), 1.02(1 \mathrm{H}, \mathrm{m}, \mathrm{H}-9), 0.96(3 \mathrm{H}, \mathrm{d}, J=6.0 \mathrm{~Hz}$, $\left.\mathrm{H}_{3}-19\right), 0.92\left(3 \mathrm{H}, \mathrm{d}, J=6.5 \mathrm{~Hz}, \mathrm{H}_{3}-27\right), 0.90(3 \mathrm{H}, \mathrm{d}$, $\left.J=7.0 \mathrm{~Hz}, \quad \mathrm{H}_{3}-26\right), \quad 0.80 \quad\left(3 \mathrm{H}, \quad \mathrm{s}, \quad \mathrm{H}_{3}-18\right) .{ }^{13} \mathrm{C} \quad \mathrm{NMR}$ $\left(125 \mathrm{MHz}, \mathrm{CD}_{3} \mathrm{OD}\right) \delta_{\mathrm{C}}: 188.9(\mathrm{C}, \mathrm{C}-3), 174.1(\mathrm{C}, \mathrm{C}-5)$, 159.9 (CH, C-1), 127.7 (CH, C-2), 124.0 (CH, C-4), 77.2 (C, C-24), $66.4\left(\mathrm{CH}_{2}, \mathrm{C}-28\right), 57.4(\mathrm{CH}, \mathrm{C}-17), 57.0(\mathrm{CH}$, C-14), 54.4 (CH, C-9), 45.6 (C, C-10), 44.0 (C, C-13), $41.1\left(\mathrm{CH}_{2}, \mathrm{C}-12\right), 37.8(\mathrm{CH}, \mathrm{C}-20), 36.9(\mathrm{CH}, \mathrm{C}-8), 35.3$ $\left(\mathrm{CH}_{2}, \mathrm{C}-7\right), 34.1\left(\mathrm{CH}_{2}, \mathrm{C}-6\right), 33.8(\mathrm{CH}, \mathrm{C}-25), 31.8\left(\mathrm{CH}_{2}\right.$, C-23), $30.1\left(\mathrm{CH}_{2}, \mathrm{C}-22\right), 29.4\left(\mathrm{CH}_{2}, \mathrm{C}-16\right), 25.5\left(\mathrm{CH}_{2}\right.$, $\mathrm{C}-15), 24.2\left(\mathrm{CH}_{2}, \mathrm{C}-11\right), 19.3\left(\mathrm{CH}_{3}, \mathrm{C}-19\right), 19.2\left(\mathrm{CH}_{3}, \mathrm{C}-21\right)$, $17.6\left(\mathrm{CH}_{3}, \mathrm{C}-27\right), 17.5\left(\mathrm{CH}_{3}, \mathrm{C}-26\right), 12.6\left(\mathrm{CH}_{3}, \mathrm{C}-18\right)$. ESIMS m/z $451[\mathrm{M}+\mathrm{Na}]^{+}$; HRESIMS $\mathrm{m} / \mathrm{z} 451.3186$ (calcd for $\mathrm{C}_{28} \mathrm{H}_{44} \mathrm{O}_{3} \mathrm{Na}, 451.3190$ ).

3.3.2. Chabrolosteroid B (2). White powder; mp 189$192{ }^{\circ} \mathrm{C} ;[\alpha]_{\mathrm{D}}^{25}-34\left(c \quad 0.72, \mathrm{CHCl}_{3}\right)$; UV $(\mathrm{MeOH}) \lambda_{\max }$ $248 \mathrm{~nm} ;$ IR (neat) $\nu_{\max } 3422,1660 \mathrm{~cm}^{-1} ;{ }^{1} \mathrm{H}$ and ${ }^{13} \mathrm{C}$ NMR, see Table 1 ; ESIMS $m / z 449$ [M+Na $]^{+}$; HRESIMS $m / z, 449.3029$ (calcd for $\mathrm{C}_{28} \mathrm{H}_{42} \mathrm{O}_{3} \mathrm{Na}, 449.3034$ ).

3.3.3. Chabrolosteroid C (3). White powder; mp 149$152{ }^{\circ} \mathrm{C} ;[\alpha]_{\mathrm{D}}^{25}-159\left(c 0.16, \mathrm{CHCl}_{3}\right) ; \mathrm{UV}(\mathrm{MeOH}) \lambda_{\max }$ $246 \mathrm{~nm} ;$ IR (neat) $\nu_{\max } 3356,1655 \mathrm{~cm}^{-1} ;{ }^{1} \mathrm{H}$ and ${ }^{13} \mathrm{C}$ NMR, see Table 1 ; ESIMS $m / z$ $451[\mathrm{M}+\mathrm{Na}]^{+}$; HRESIMS $m / z, 451.3186$ (calcd for $\mathrm{C}_{28} \mathrm{H}_{44} \mathrm{O}_{3} \mathrm{Na}, 451.3190$ ).

3.3.4. Preparation of $(S)$ - and $(\boldsymbol{R})$-MTPA esters of 1 . To a solution of $1(1.0 \mathrm{mg})$ in pyridine $(50 \mu \mathrm{L})$ was added (-)-MTPA chloride $(5 \mu \mathrm{L})$, and the solution was allowed to stand overnight at room temperature. The reaction mixture was added with $1 \mathrm{~mL}$ of water, followed by extraction with $\mathrm{CH}_{2} \mathrm{Cl}_{2}(1 \mathrm{~mL} \times 3)$. The $\mathrm{CH}_{2} \mathrm{Cl}_{2}$ soluble layers were combined, dried over anhydrous $\mathrm{MgSO}_{4}$, and evaporated. The residue was subjected to short $\mathrm{Si}$ gel column chromatography using EtOAc- $n$-hexane $(1: 2)$ to yield the $(S)$-MTPA ester of $1(0.5 \mathrm{mg}, 34 \%)$. The same procedure was applied to obtain the $(R)$-MTPA ester of $1(0.5 \mathrm{mg}, 34 \%)$ from the reaction of (+)-MTPA chloride with $\mathbf{1}$ in pyridine.

\subsection{Cytotoxicity testing}

Cell lines were purchased from the American Type Culture Collection (ATCC). Cytotoxicity assays of the test 
compounds 1-3 were performed using MTT [3-(4,5dimethylthiazole-2-yl)-2,5-diphenyltetrazolium bromide] colorimetric method. ${ }^{7,8}$

\section{Acknowledgements}

Financial support was provided by Ministry of Education (C030313) and National Science Council of Taiwan (NSC 95-2323-B-110-002) to J.-H.S.

\section{References and notes}

1. Sheu, J.-H.; Su, J.-H.; Sung, P.-J.; Wang, G.-H.; Dai, C.-F. J. Nat. Prod. 2004, 67, 2048-2052.
2. Su, J.-H.; Ahmed, A. F.; Sung, P.-J.; Wu, Y.-C.; Sheu, J.-H. J. Nat. Prod. 2005, 68, 1651-1655.

3. Duh, C.-Y.; El-Gamal, A. H.; Song, P.-Y.; Wang, S.-K.; Dai, C.-F. J. Nat. Prod. 2004, 67, 1650-1653.

4. Zhang, G.-W.; Ma, X.-Q.; Kurihara, H.; Zhang, C.-X.; Yao, X.-S.; Su, J.-Y.; Zeng, L.-M. Org. Lett. 2005, 7, 991-994.

5. Iorizzi, M.; Bryan, P.; McClintock, J.; Minale, L.; Palagiano, E.; Maurelli, S.; Riccio, R.; Zollo, F. J. Nat. Prod. 1995, 58, 653-671.

6. Wang, W.; Jang, H.; Hong, J.; Lee, C.-O.; Im, K. S.; Bae, S.-J.; Jung, J.-H. J. Nat. Prod. 2004, 67, 1654-1660.

7. Alley, M. C.; Scudiero, D. A.; Monks, A.; Hursey, M. L.; Czerwinski, M. J.; Fine, D. L.; Abbott, B. J.; Mayo, J. G.; Shoemaker, R. H.; Boyd, M. R. Cancer Res. 1988, 48, 589-601. 8. Scudiero, D. A.; Shoemaker, R. H.; Paull, K. D.; Monks, A.; Tierney, S.; Nofziger, T. H.; Currens, M. J.; Seniff, D.; Boyd, M. R. Cancer Res. 1988, 48, 4827-4833. 